\title{
ORIGIN OF THE BASAL ICE LAYER FROM ALPINE GLACIERS INDIGATED BY ITS GHEMISTRY
}

\author{
By R. A. Souchez and R. D. Lorrain \\ (Laboratoire de Géomorphologie, Faculté des Sciences, Université Libre de Bruxelles, \\ Avenue F. D. Roosevelt, 5o, B-ro5o Bruxelles, Belgium)
}

\begin{abstract}
The basal ice layer of Alpine glaciers, the thickness of which can reach more than one metre, generally appears as a sequence composed of layers of bubble-poor ice $0.5^{-3} \mathrm{~cm}$ thick and dirt layers containing dispersed rock fragments. Locally, debris-free bubbly ice is also present in the sequence. This basal layer exists on the lee side of rock protuberances or along the marginal part of the glacier. Three geochemical
\end{abstract} characteristics shed some light on its origin:

(a) The high calcium content of basal ice sliding over limestones from the north side of Glacier de Tsanfleuron can be successfully predicted from considerations of the phase relations in regelating subglacial solutions in approximate equilibrium with subglacial calcite deposits.

(b) The $(\mathrm{Na}+\mathrm{K}) /(\mathrm{Ca}+\mathrm{Mg})$ ratio of bubble-poor basal ice from Glacier de Tsijiore Nouve which flows over gneissic rocks is significantly higher than this ratio in other samples taken in the same environment (glacier ice, melt water). This may be explained by refreezing of squeezed water, the ionic composition of which is governed by selective diffusion of ions during squeezing and/or by the water being forced through mud layers as demonstrated by us at the base of Glacier d'Argentière (Souchez and Lorrain, 1975).

(c) The Lead-2 Io activity per kg of basal ice from the south side of Glacier de Tsanfleuron is greater than that of the glacier ice immediately above, which indicates that it is younger despite percolation effects. This can be explained if recent ice accretion has occurred at the base of relatively old glacier ice. Accretion of blowing snow has been found to occur under the southern margin of the glacier.

RÉsumé. Origine de la couche basale des glaciers alpins indiquée par sa composition chimique. La couche basale des glaciers alpins, dont l'épaisseur peut atteindre plus d'un mètre, se présente généralement comme une séquence composée de lits de 0,5 à $3 \mathrm{~cm}$ d'épaisseur de glace sans bulles et de lits de particules contenant des fragments rocheux dispersés. Localement, de la glace bulleuse sans particules apparaît également dans la séquence. Cette couche basale existe à l'aval des protubérances du lit rocheux ou le long du bord du glacier. Trois caractéristiques géochimiques éclairent son origine:

(a) la forte concentration en Ca de la glace basale du flanc nord du glacier du Tsanfleuron qui glisse sur un substratum calcaire peut être estimée de manière très satisfaisante sur base des relations de phase des eaux sous-glaciaires à partir desquelles se forment la glace basale et les précipitations calcaires qui recouvrent la roche en place.

(b) le rapport $(\mathrm{Na}+\mathrm{K}) /(\mathrm{Ca}+\mathrm{Mg})$ de la glace sans bulles du glacier de Tsijiore Nouve qui s'écoule sur des roches gneissiques est nettement plus élevé que celui de tout autre échantillon prélevé dans le même environnement (glace de glacier, eaux de fusion). La situation peut s'expliquer si l'eau exsudée subit un effet de séparation chimique comme celui que nous avons décrit précédemment au glacier d'Argenière ou draine sélectivement les saumures, le phénomène étant gouverné par la diffusion (Souchez et Lorrain, 1975).

(c) l'activité du Plomb 2 10 par $\mathrm{kg}$ de glace basale du flanc droit du glacier de Tsanfleuron est plus élevée que celle de la glace de glacier située immédiatement au-dessus. Cette particularité indique, en dépit des influences de la percolation, que la glace basale est plus jeune que la glace de glacier qui la surmonte. Ceci ne peut s'expliquer que par pénétration et métamorphisme de neige soufflée récente sous le glacier à la faveur de décollements marginaux.

Zusammenfassung. Der Ursprung der Eisschicht am Grunde von Alpengletschern, hergeleitet aus ihrer chemischen Zusammensetzung. Die Eisschicht am Grunde von Alpengletschern, deren Dicke mehr als einen Meter erreichen kann, erscheint im allgemeinen als eine Folge von $0.5-3 \mathrm{~cm}$ dicken blasenarmen Eisschichten und Schmutzschichten, die verstreute Felsbrocken enthalten. Lokal ist auch schuttfreies, blasenreiches Eis in der Folge anzutreffen. Diese Grundschicht tritt auf der Leeseite von Felshindernissen oder längs der Randpartien der Gletscher auf. Drei geochemische Besonderheiten erhellen ihren Ursprung in gewissem Masse:

(a) Der hohe Kalziumgehalt von Grundeis, das auf der Nordseite des Tsanfleuron-Gletschers über Kalksteine gleitet, kann erfolgreich aus der Betrachtung der Phasenbeziehungen in wiedergefrierenden subglazialen Lösungen hergeleitet werden, die sich annähernd im Gleichgewicht mit subglazialen
Kalzitablagerungen befinden.

(b) Das Verhältnis von $\mathrm{Na}+\mathrm{K}$ zu Ca $+\mathrm{Mg}$ in blasenarmem Grundeis des Tsijiore Nouve-Gletschers, das über Gneisfelsen fliesst, ist beträchtlich höher als das von anderen Proben, die in der Umgebung entnommen wurden (Gletschereis, Schmelzwasser). Dies kann aus dem Wiedergefrieren von gepresstem Wasser erklärt werden, dessen Ionenzusammensetzung durch selektive Diffusion von austretenden Ionen während der Pressung und/oder durch Druckfliessen über Schlammschichten gesteuert wird, wie wir bereits früher am Grunde des Glacier d'Argentière gezeigt haben (Souchez und Lorrain, 1975). 
(c) Die Blei-2 ro-Aktivität pro kg Grundeis von der Südseite des Tsanfleuron-Gletschers ist höher als die im Gletschereis unmittelbar darüber, woraus sich trotz der Sickerungseinflüsse dessen relativ junges Alter ergibt. Dies lässt sich daraus erklären, dass ständig ein Aufwachsen von Eis am Grunde jes relativ alten Gletschereises stattfand. Das Auftreten des Aufwachsens von Driftschnee wurde unter dem Südrand des Gletschers festgestellt.

\section{INTRODUCTION}

The origin of glacier basal ice layers (B.I.L.) has held the attention of many authors. Several studies were made on a theoretical basis (Weertman, I96r; Lliboutry, $1964-65$, p. 689). Direct observations were also carried out. For instance, at the base of the Blue Glacier (Washington, U.S.A.), crystallographic investigations supported by laboratory experiments led to the recognition of regelation phenomena (Kamb and LaChapelle, 1964). Other field observations have confirmed this (Boulton, 1970; Clapperton, 1975; Vivian, I975) and have permitted a better understanding of ice formation at the glacier-bedrock interface, although in these studies the chemistry of basal ice was not investigated. The present authors (Souchez and Lorrain, 1975) suggested that a knowledge of the chemical composition of basal ice would help in understanding its formation and clarifying the processes operating at this interface. Approximately at the same time, the effect of subglacial chemical processes on regelation phenomena and glacier sliding was studied theoretically by Hallet ( $1976[\mathrm{a}],[\mathrm{b}]$ ). This author has put forward the role played by the phase relations of the subglacial water-ice system.

In a recent paper (Hallet and others, in press), we and Hallet have shown a very good agreement between the chemical composition of basal ice from an Alpine glacier sliding over limestone and that predicted from his model.

In this paper, we present the results of chemical analyses of ice sampled at the base of several Alpine glaciers. In many of the cases studied, these results clearly indicate the nature of the processes by which basal ice forms.

\section{Distribution AND GHARACTERISTICS OF THE B.I.L.}

We have examined five examples of B.I.L. localized under four Alpine glaciers all situated in Switzerland (Fig. I). In each case, these B.I.L. are visibly different from the "normal" glacier ice which overlays them. In the one observed at the base of Glacier de Trient which is located on the Swiss side of the Mont Blanc massif, a homogeneous firn layer about I m thick appears at the base of the glacier front. It is very bubbly and whiter than glacier ice, free of foliation, and composed of compressed snow partially transformed into ice. This feature is characteristic of very active advancing glaciers. Glacier de Trient has been advancing from $195^{8}$ until now (except during the $1960 / 6$ I period) at an average rate of I 7.4 m/year. Avalanche snow is overridden by the glacier and progressively transformed into a frontal layer of basal firn or ice (Kasser and Aellen, 1974).

The other examples show that the B.I.L. is generally stratified. It is composed of a sequence of different types of layers with variable thickness. Three elementary layers constitute the basis for such sequences but are not always present together:

(a) a bubble-poor ice layer about 0.2 to $3 \mathrm{~cm}$ thick, nearly particle-free,

(b) a very dirty layer of about the same thickness containing more mineral particles than ice,

(c) a very bubbly but particle-free ice layer, the thickness of which is very variable from one sequence to another.

It was possible to observe two different types of such sequences at the base of Glacier de Tsanfleuron which is located, on limestones, north-west of the town of Sion in Canton Valais. At the base of the northern margin of the small tongue which terminates this plateau glacier 


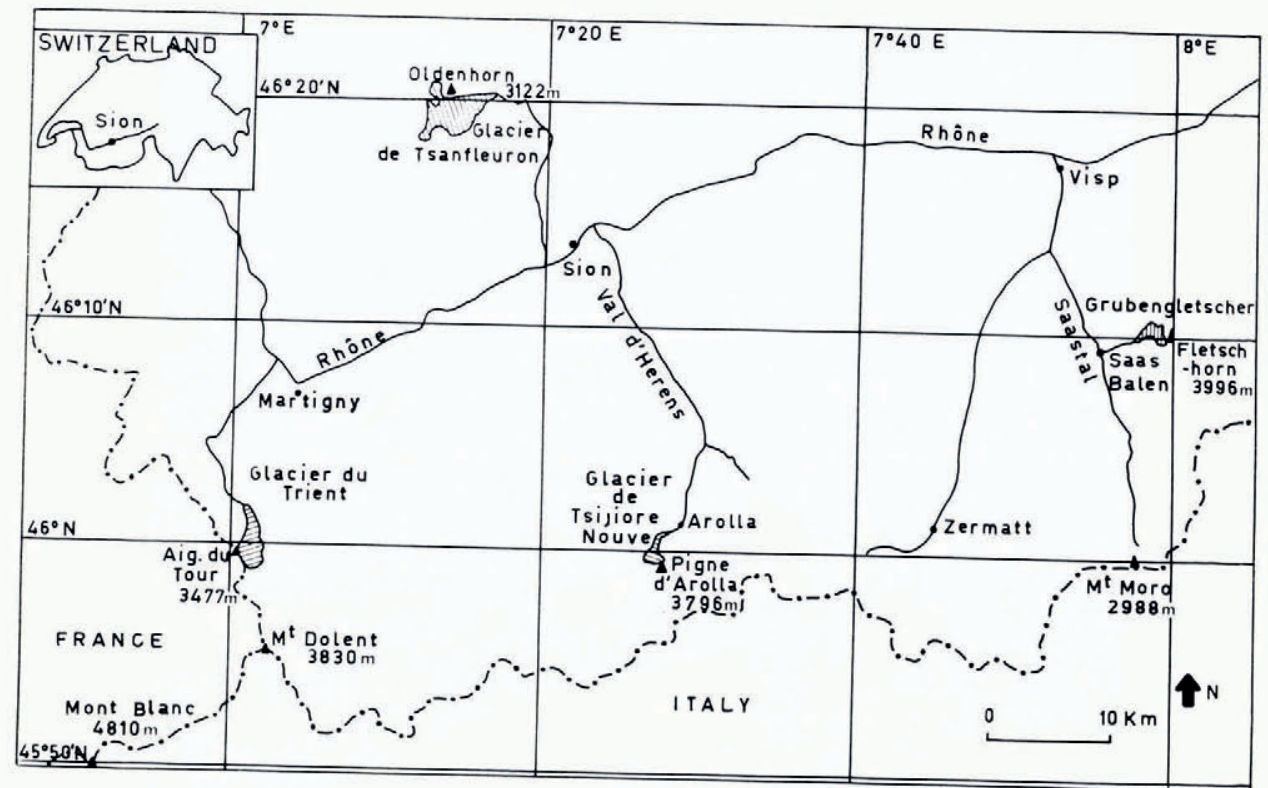

Fig. I. Location of the four glaciers studied.

in its north-eastern part, we studied a B.I.L. about $20 \mathrm{~cm}$ thick, composed of thin layers of bubble-poor ice ( $\mathrm{I}$ or $2 \mathrm{~cm}$ thick). It contains dispersed rock fragments up to $\mathrm{I} 5 \mathrm{~cm}$ long. Along the southern margin of the same tongue, a completely different situation occurs. In contrast with the northern margin, which consists of a sub-vertical ice ramp, the southern margin is a relatively gentle slope and, from place to place, the glacier loses contact with the bedrock. Some natural subglacial tunnels are thus accessible and allow the B.I.L. to be seen very clearly. It consists of a wedge of ice; its thickness reaching $\mathrm{I}$ or $2 \mathrm{~m}$ at the glacier margin diminishes gradually towards the interior, disappearing completely after about 8 to $10 \mathrm{~m}$. The three elementary layers described above are present with a striking dominance of thick bubble-rich layers (up to $20 \mathrm{~cm}$ ). These layers are separated by dirty layers locally associated with thin bubble-free ice (Fig. 2).

A somewhat different sequence has been encountered at the base of the right side of Glacier de Tsijiore Nouve which is flowing over gneissic rocks, at the head of the Arolla branch of the Val d'Hérens (Valais). The site is located just below a large ice fall. At this point, access to the B.I.L. is possible between the valley slope and the glacier margin because of a bend in the valley. The sequence of ice layering may be clearly seen in Figure 3. The bubblerich layers are thick (up to $20 \mathrm{~cm}$ ) and are separated from each other by a series of bubblepoor layers, each of them being overlain by a thin particle layer. The bubble-poor layers have a mean thickness of about $\mathrm{I} \mathrm{cm}$ (maximum $2 \mathrm{~cm}$ ) and the particle layers, of about $0.5 \mathrm{~cm}$ (maximum I cm). Each series of these two types of layers reaches a thickness of Io to I $5 \mathrm{~cm}$. The whole sequence was observable over a height of about $2 \mathrm{~m}$. Small rock fragments (up to $5 \mathrm{~cm}$ long) are dispersed in the layers.

Another sequence is to be found in a tunnel dug at the base of the Grubengletscher which is flowing over gneissic rocks in the Saastal. The tunnel is excavated partly in the ground moraine of the glacier and partly in the ice itself to channel the water of an ice-dammed lake. The tongue of the glacier is flowing in a permafrost zone as pointed out by Haeberli (1976). Temperature measurements made by this author indicate that the ice at this point is clearly below the pressure-melting point. In this last example, the sequence has a total thickness of 


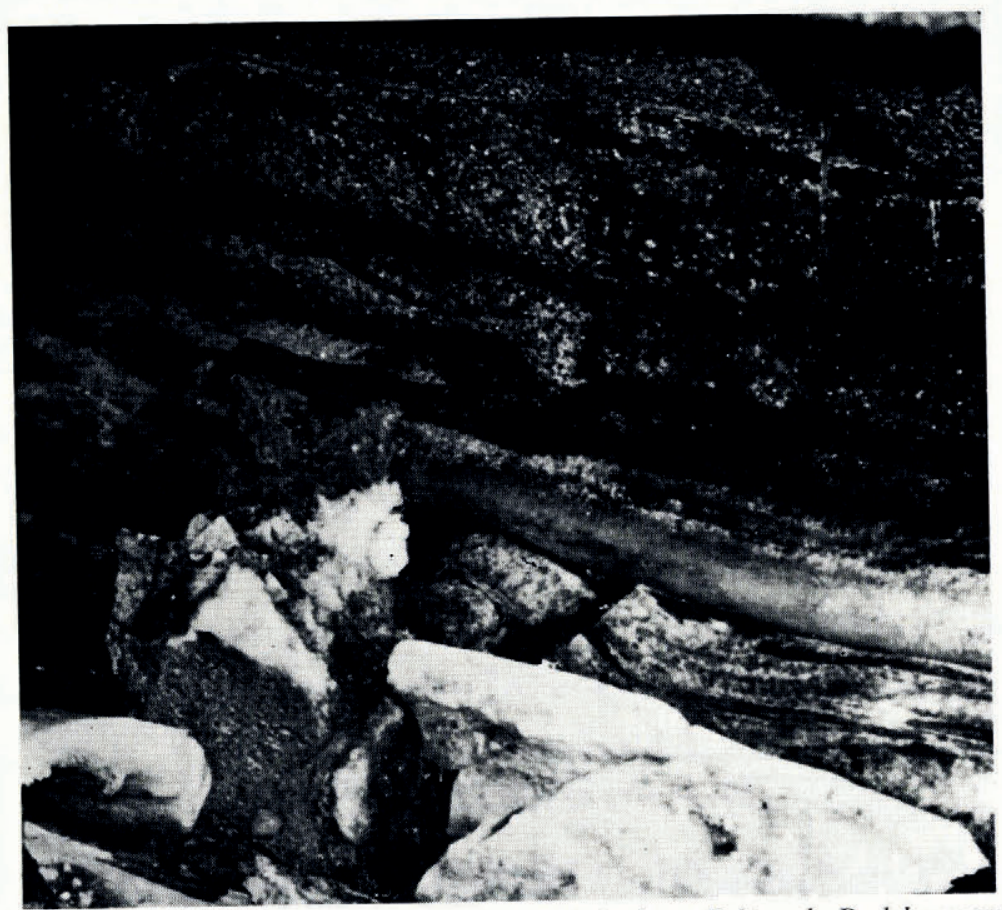

Part of the B.I.L. of Glacier de Tsanfleuron south-side margin in the studied tunnel. Dark layers consist of bubble-poor ice, light and dotted layers are bubble-rich ice. Wind-drift ice is incorporated at the base. The height of the wall is approximately $120 \mathrm{~cm}$.

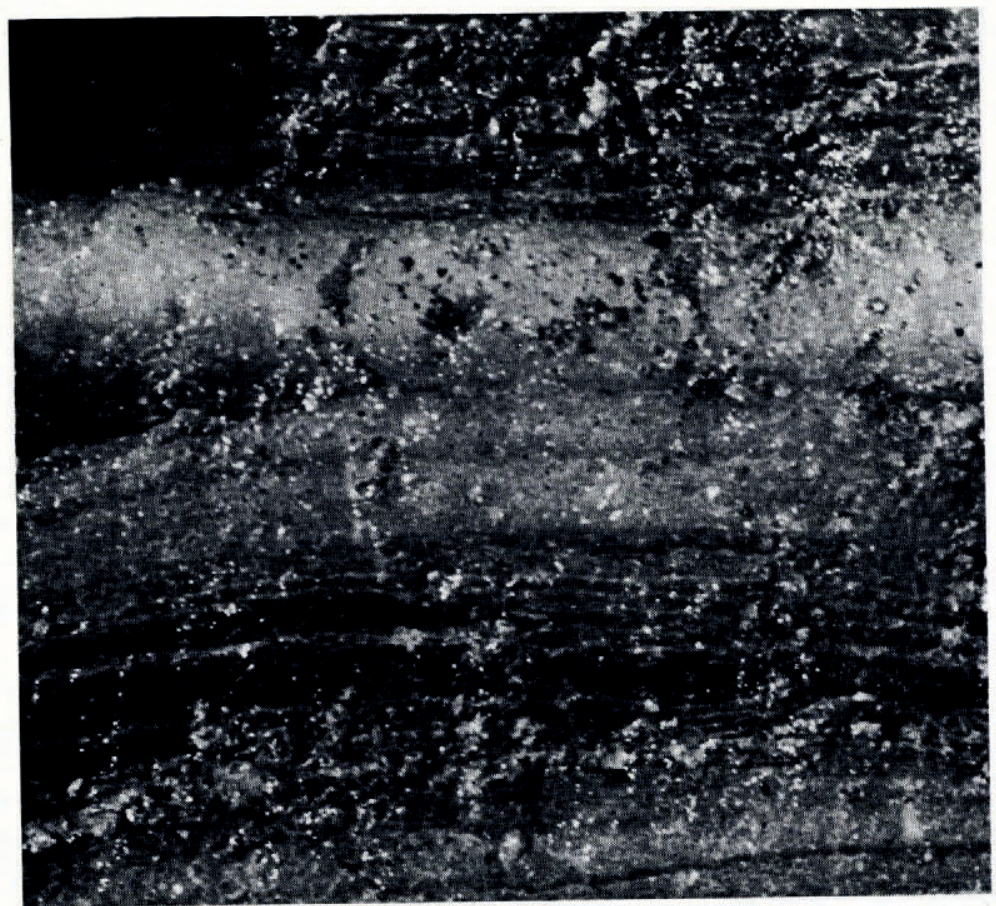

Fig. 3. Part of the B.I.L. of Glacier de Tsijiore Nouve. Dark layers consist of bubble-poor ice, thick, light layers of bubble-rich ice. Thin particle layers are interbedded with bubble-poor ice. Total thickness of the sequences on this picture is $60 \mathrm{~cm}$. 
about $\mathrm{I} \mathrm{m}$ and is composed of bubble-poor layers about $2 \mathrm{~cm}$ thick interbedded with thin dirty layers and, from place to place, with an isolated thin bubbly layer. The dirty layers have a mean thickness of about $0.5 \mathrm{~cm}$ (maximum $\mathrm{I} \mathrm{cm}$ ). They often contain rock fragments which can reach twice the normal layer thickness or more so that they interrupt one or more bubblepoor ice layers (Fig. 4). The isolated bubbly layers appear in a proportion of about one per twenty bubble-poor layers and have a mean thickness of about $\mathrm{I} \mathrm{cm}$.

This description of different types of stratified B.I.L. shows that particle layers are associated with bubble-poor layers and that bubble-rich layers represent a variable fraction of the sequence, from about a half to a negligible proportion.

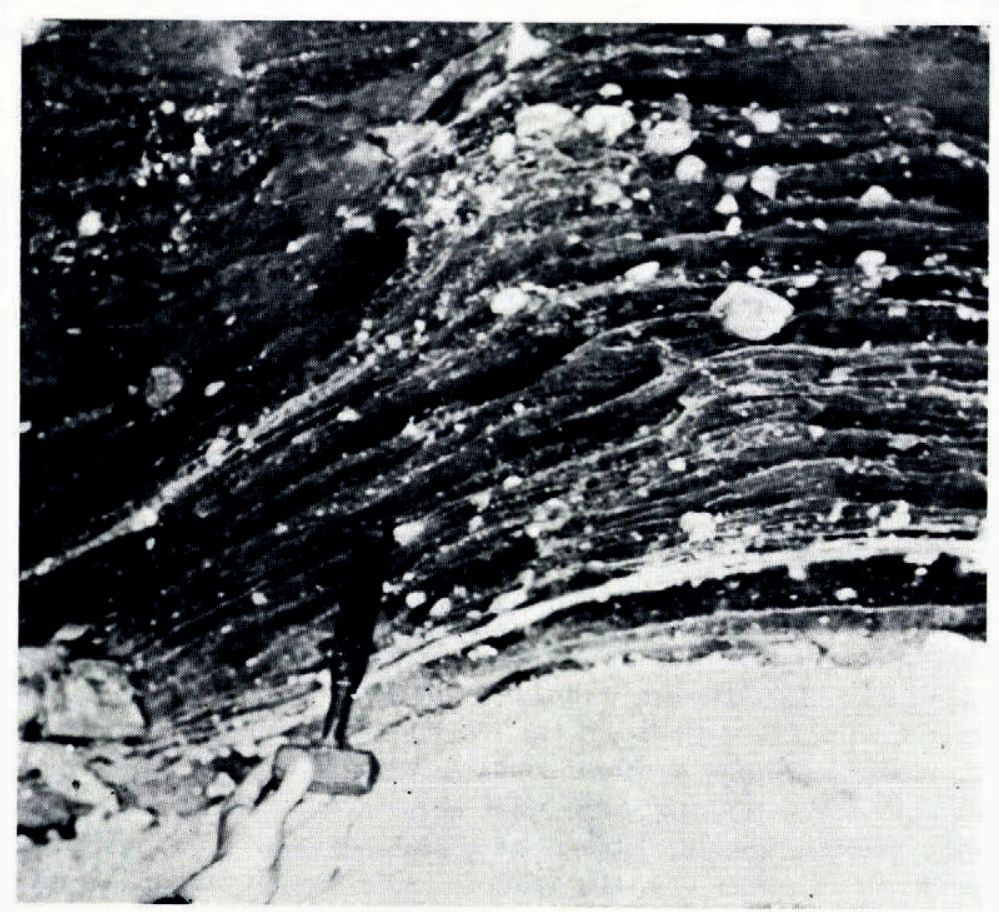

Fig. 4. Part of the B.I.L. of Grubengletscher in the subglacial tunnel. Dark layers consist of bubble-poor ice, thin, light layers of dirty ice. Numerous rock fragments are dispersed in the sequence. The hammer which is $20 \mathrm{~cm}$ long stands on a big boulder of ground moraine.

\section{Methods OF SAMPLiNG AND ANALYSIS}

From the five B.I.L. described above, we sampled the four which are stratified and determined the composition of major cations in the ice by analysing the samples, in liquid form, by atomic absorption spectrophotometry.

The methods used to collect and treat the samples were devised to reduce contamination to a level comparable with the background noise level of the instrument and to control chemical changes caused by melting the samples. All samples were taken with the aid of a "Teflon"-coated USA-CRREL 3 inch $(7.5 \mathrm{~cm})$ ice corer. The cores were sliced along layer boundaries with a non-contaminant saw.

To determine the main cationic composition, two ice cores were taken at each sampling site. One was transferred in the frozen state to a press-filtered air-supplied laboratory; the other was treated in a field laboratory using a procedure we have described elsewhere (Hallet 
and others, in press). Samples having a particle content of more than $0.5 \mathrm{~g} / \mathrm{kg}$ ice were systematically eliminated because of the potential importance of ion exchange and dissolution phenomena (Souchez and others, 1973). No significant differences were noticed between these two groups of samples.

${ }^{210} \mathrm{~Pb}$ activity measurements were, for logistic reasons, limited to the south side of the tongue of the Glacier de Tsanfleuron. For these measurements, the chemical and low-level counting techniques were the same as those previously described by Crozaz and others (1964) and Crozaz (unpublished), and indeed the same apparatus was used. About $5 \mathrm{~kg}$ of ice were taken at each sampling site. Before melting, a Pb-carrier in concentrated nitric acid was added to the samples. Because of potential influence of melt water in a temperate glacier, no attempt was made to date the ice. Only a general comparison between the ${ }^{210} \mathrm{~Pb}$ activity of the B.I.L. and of the ice immediately above was attempted. The validity of such an approach is discussed with the results below.

\section{Cationic composition of the B.I.L.}

In our study with B. Hallet (Hallet and others, in press), we were able to explain quantitatively the calcium content of the B.I.L. from the north side of Glacier de Tsanfleuron from consideration of the phase relations in regelating subglacial solutions in approximate equilibrium with subglacial calcite deposits appearing on the lee side of rock protuberances. The calculated eutectic Ca concentration determined by the equation

$$
\mathrm{Ca}=0.0282\left(p \mathrm{CO}_{2}\right)^{0.365}
$$

(where the carbon dioxide partial pressure, $p \mathrm{CO}_{2}$, is expressed in bars and the Ca concentration in eq $\mathrm{l}^{-1}$ ), used in conjunction with an experimental distribution coefficient (o.or) which characterizes the solute partitioning during growth, can indeed yield estimates of the Ca content of the basal ice.

The minimum calcium content of the B.I.L. which would result if regelation is important can be easily estimated. If the subglacial water is at atmospheric pressure and in equilibrium with the carbon dioxide partial pressure of the atmosphere we obtain, using Equation (I) with 0.75 bar for the pressure (the altitude of the region is more than $2500 \mathrm{~m}$ a.s.1.) and $0.03 \%$ for the carbon dioxide volume content, 0.000225 bar for $p \mathrm{CO}_{2}$ and thus o.ooI $3 \mathrm{eq}^{-\mathrm{I}}$ for the Ca content of the freezing subglacial water. Taking into account a distribution coefficient of o.or, the Ca content of basal ice would be $\mathrm{I} 3 \mu \mathrm{eq} 1^{-1}$. The value o.or for the distribution coefficient is rather low. In Hallet's experiments (Hallet, I976[a]) and in our own unpublished ones, values of 0.02 were found, or even up to 0.05 if the rate of freezing is increased, and these will probably be more representative. This means that $13 \mu$ eq $1^{-1} \mathrm{Ca}$ is the minimum value for basal ice if the B.I.L. is to be explained by regelation in equilibrium with calcite.

Several B.I.L. studied in the Alps do not reach such a Ca concentration. The B.I.L. of Glacier de Tsijiore Nouve described above is worth considering in this respect. As a result of weathering of silicate rocks by carbon dioxide and of limited occurrence of calcite in this environment, hydrocarbonate and calcium ions are present in the subglacial water, and therefore it is theoretically possible to reach by freezing the concentration level at which calcium carbonate will precipitate. Table I gives data for the cationic composition of three selected types of ice: glacier ice, and the bubbly and bubble-poor ice layers of the B.I.L. Values higher than ${ }^{3} \mu_{\text {eq }}{ }^{-1}$ Ca are not reached and thus the preceding model cannot apply. Table I also shows that the bubble-poor ice of the B.I.L. is distinctly different from the other types by a higher total cation content and a higher $(\mathrm{Na}+\mathrm{K}) /(\mathrm{Ca}+\mathrm{Mg})$ ratio.

Members of our laboratory (Lemmens and Roger, in press) have investigated the relationships between chemical concentration and discharge in the melt stream of the glacier frontal zone. 
Table I. Cationic composition of Glacier de Tsijiore Nouve samples

\begin{tabular}{|c|c|c|c|c|c|c|c|c|c|}
\hline & \multicolumn{3}{|c|}{$\begin{array}{c}\text { Glacier ice } \\
\text { (18 samples) } \\
\mu \mathrm{eq} \mathrm{I}^{-\mathrm{I}}\end{array}$} & \multicolumn{3}{|c|}{$\begin{array}{c}\text { Basal bubbly ice } \\
\text { (I I samples) } \\
\text { req } \mathrm{l}^{-1}\end{array}$} & \multicolumn{3}{|c|}{ 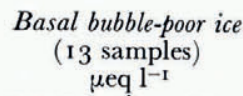 } \\
\hline & mean & $\min$. & $\max$. & mean & min. & $\max$. & mean & min. & $\max$. \\
\hline & 0.8 & 0.3 & 2.0 & 1.4 & 0.5 & 2.3 & 2.9 & I. 3 & 5.2 \\
\hline K & 0.9 & 0.3 & I. 4 & I. 1 & o. I & 2.4 & 2.4 & 0.8 & 3.7 \\
\hline $\mathrm{Ca}$ & 4.2 & I. 9 & 9.6 & 4.1 & 2.2 & $7 \cdot 3$ & 6.4 & $3 \cdot 4$ & 10.7 \\
\hline $\mathrm{Mg}$ & 2.6 & I. 4 & 7.1 & 2.7 & 2.1 & $4 \cdot 3$ & 3.1 & I. 9 & $4 \cdot 4$ \\
\hline $\mathrm{Na}+\mathrm{K}+\mathrm{Ca}+\mathrm{Mg}$ & 8.5 & $4 \cdot 3$ & I8.0 & 9.2 & $5 \cdot \mathrm{I}$ & I5. I & 14.8 & 8.o & 22.8 \\
\hline$(\mathrm{Na}+\mathrm{K}) /(\mathrm{Ca}+\mathrm{Mg})$ & 0.28 & 0.09 & 0.49 & 0.34 & 0.1 5 & $0.5 \mathrm{I}$ & $0.5^{8}$ & 0.34 & $0.8_{5}$ \\
\hline
\end{tabular}

Good negative correlations exist if each cationic content is plotted against discharge on logarithmic scales: correlation coefficients are respectively -0.82 for $\mathrm{Na},-0.69$ for $\mathrm{K}$, -0.95 for $\mathrm{Ca},-0.95$ for $\mathrm{Mg}$, and are significant at a confidence level of 0.999 . The ratio $(\mathrm{Na}+\mathrm{K}) /(\mathrm{Ca}+\mathrm{Mg})$ slightly decreases as concentration increases; its maximum value is about 0.10 , which is not far from the values obtained on supraglacier streams (0.12). On the other hand, experiments were carried out at $0^{\circ} \mathrm{C}$ in a cold laboratory leaving in contact for various periods the fine particles $\left(<5^{\circ} \mu \mathrm{m}\right)$ of the morainic deposits from Glacier de Tsijiore Nouve and melted ice from the same glacier. The results indicate that the $(\mathrm{Na}+\mathrm{K}) /(\mathrm{Ca}+\mathrm{Mg})$ ratio decreases in the course of time, a value as low as 0.18 being recorded after only i min of contact. The two facts developed above indicate that water in contact with ice and with the bedrock in the area of Glacier de Tsijiore Nouve never reach a $(\mathrm{Na}+\mathrm{K}) /(\mathrm{Ca}+\mathrm{Mg})$ ratio as high as $0.5^{8}$, which is the mean value for bubble-poor ice of the B.I.L. A possible reduction in the $(\mathrm{Ca}+\mathrm{Mg})$ content of the water by sub-glacial carbonate deposition is precluded because the calcium concentration in the ice is much lower than would be obtained by freezing water saturated with $\mathrm{CaCO}_{3}$. In addition, there is no calcite deposition on the lee side of rock obstacles. Selective incorporation of cations during freezing will decrease the $(\mathrm{Na}+\mathrm{K}) /(\mathrm{Ca}+\mathrm{Mg})$ ratio in ice as compared to water since the divalent ions are preferentially incorporated (Malo and Baker, I968). Simple refreezing of melt water circulating at the icebedrock interface cannot thus explain the higher $(\mathrm{Na}+\mathrm{K}) /(\mathrm{Ca}+\mathrm{Mg})$ ratio of bubble-poor ice of the B.I.L.

Robin (1976) discusses the pressure-melting mechanism within the basal ice mass and indicates that excess water is formed in zones of high-pressure ice, up-stream of obstacles. If this water is squeezed out of the ice by the pressure, a simple heat pump exists that will tend to cool the basal ice. This mechanism can produce cold patches at the ice-rock interface. Robin suggests that air bubbles would tend to be expelled along with the water being squeezed out of the capillaries, which partially explains the bubble-poor nature of the B.I.L. Robin's process probably occurs at the base of Glacier de Tsijiore Nouve but is not in itself sufficient to explain the peculiar composition of the bubble-poor ice layers of the B.I.L. Indeed, if water and air are expelled, the chemical content of the ice is likely to change because of selective flushing-out of ions. Thus a lower total ion content and a lower $(\mathrm{Na}+\mathrm{K}) /$ $(\mathrm{Ca}+\mathrm{Mg})$ ratio may be expected due to a more rapid migration of alkalis (which have larger diffusion coefficients than $\mathrm{Ca}$ or $\mathrm{Mg}$ ), which is the reverse of the situation observed here. As a corollary, the squeezed water may be selectively enriched in alkalis by the same mechanism. On the other hand, forcing of squeezed water across a mud layer at the base may also produce an increase in $(\mathrm{Na}+\mathrm{K}) /(\mathrm{Ca}+\mathrm{Mg})$ ratio (Souchez and others, r973; Souchez and Lorrain, i975). Thus, the peculiar chemical characteristics of bubble-poor ice from the B.I.L. may be explained by the refreezing of squeezed water circulating at the ice-bedrock interface. This process involves basal accretion of ice. The squeezed water does not have to be considerably enriched before freezing. Indeed, location of this B.I.L. along the margin of Glacier de Tsijiore Nouve indicates that cold air flowing beneath the glacier can 
explain the refreezing and thus the rate of freezing can be quite rapid so that a 5 to $10 \%$ distribution coefficient can apply (Gross, I 968 ).

The higher total ion content and the higher $(\mathrm{Na}+\mathrm{K}) /(\mathrm{Ca}+\mathrm{Mg})$ ratio of bubble-poor ice of the B.I.L. as compared with interbedded bubbly ice is not a situation unique to Glacier de Tsijiore Nouve. The same characteristics apply to Grubengletscher (Table II), where refreezing is mainly due to the existence of permafrost beneath the glacier.

Table II. Cationic composition of the Gruben Glacier samples

\begin{tabular}{|c|c|c|c|c|c|c|c|c|c|}
\hline & \multicolumn{3}{|c|}{ 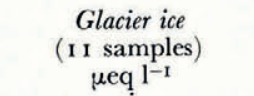 } & \multicolumn{3}{|c|}{$\begin{array}{c}\text { Basal bubbly ice } \\
\text { (6 samples) } \\
\text { ueq 1-1 }\end{array}$} & \multicolumn{3}{|c|}{$\begin{array}{c}\text { Basal bubble-poor ice } \\
\text { (13 samples) } \\
\text { нeq } 1^{-1}\end{array}$} \\
\hline & mean & $\min$. & $\max$. & mean & $\min$. & $\max$. & mean & $\min$. & $\max$. \\
\hline $\mathrm{Na}$ & I. 4 & 0.9 & 2.9 & 2.4 & 1.0 & $3 \cdot 7$ & $4 \cdot 1$ & 1.5 & 6.4 \\
\hline $\mathrm{K}$ & 1.0 & 0.5 & 1.7 & 2.2 & 0.9 & 4.1 & $3 \cdot 4$ & I. I & 5.6 \\
\hline $\mathrm{Ca}$ & 3.6 & 1.6 & 4.6 & $5 \cdot 5$ & 2.5 & 7.8 & 7.1 & 2.8 & 14.4 \\
\hline $\mathrm{Mg}$ & 2.3 & 1.3 & 3.6 & 3.0 & 2.2 & 4.5 & 4. $\mathrm{I}$ & 2.6 & 7.2 \\
\hline $\mathrm{Na}+\mathrm{K}+\mathrm{Ca}+\mathrm{Mg}$ & 8.4 & 5.2 & II.O & I3.I & 6.9 & 16.9 & 18.7 & 8.6 & 28.0 \\
\hline$(\mathrm{Na}+\mathrm{K}) /(\mathrm{Ca}+\mathrm{Mg})$ & 0.44 & 0.23 & 0.79 & $0.5^{6}$ & $0.3^{1}$ & 0.82 & 0.71 & $0.4^{2}$ & I. 13 \\
\hline
\end{tabular}

The bubbly ice of the B.I.L. at Glacier de Tsijiore Nouve and at the Grubengletscher has a chemical composition in major cations intermediate between glacier ice and bubble-poor ice layers. More information is clearly needed to explain this. In view of what will be developed in the next section, a wind-drift origin is possible. Such an origin would be in accordance with the greater thickness of bubbly ice in the B.I.L. at Glacier de Tsijiore Nouve which is developed along the marginal part of the glacier.

$210 \mathrm{~Pb}$ Activity OF THE B.I.L.

This investigation was carried out on ice samples from a natural subglacial tunnel extending into the wedge-shaped B.I.L. and glacier ice of the south side of Glacier de Tsanfleuron. The ${ }^{210} \mathrm{~Pb}$ activity in $\mathrm{dpm} / \mathrm{kg}$ of ice from the B.I.L. is compared in Table III with the activity of glacier ice situated immediately above. Percolation of melt water through small crevices in the ice can modify the ${ }^{210} \mathrm{~Pb}$ activity by migration of this radionuclide along with the water. Therefore, considering temperate glacier ice as a closed system may be a rough approximation. However the internal consistency of the results in Table III probably signifies that this approximation is reasonable for the southern side of the Glacier de Tsanfleuron tongue. The filtration role played by the particles in the ice which tend to absorb migrating radionuclides (Prantl and others, 1973) must also be considered. This effect can be discounted in the present case since particles were carefully eliminated before sample melting had taken place, and since dirt extracted from a known volume of ice only shows negligible activity due to ${ }^{210} \mathrm{~Pb}$.

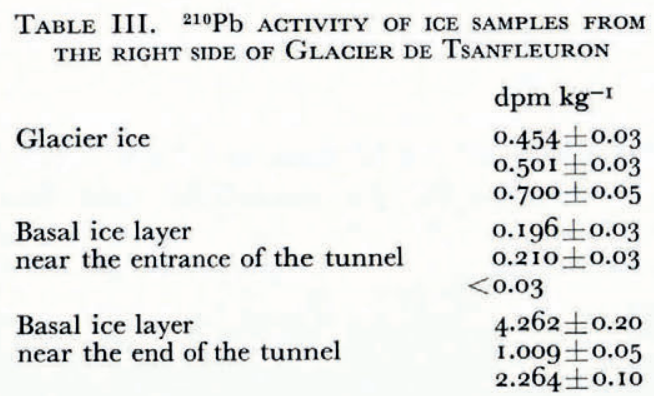


Table III shows that values of activity for glacier ice are well grouped around the mean, whereas for the wedge of basal ice below, two groups can be distinguished: low values of activity are encountered near the margin, probably because of more influence of melt water, and high values - higher than for the glacier ice above- are obtained from samples near the end of the subglacial tunnel. Melt water may have a highly variable ${ }^{210} \mathrm{~Pb}$ activity depending on its origin (old glacier ice, recent snowbank) and on the relative mobility of this radionuclide during partial melting.

The fact that basal ice at the extremity of the wedge has substantially higher ${ }^{210} \mathrm{~Pb}$ activity values than glacier ice immediately above, substantiates an origin for that ice by basal accretion. Blowing snow deposited in a marginal crevasse under glacier ice is a normal feature of this margin of Glacier de Tsanfleuron. By compression induced by the overlying glacier ice, blowing snow, rock fragments, and regelating melt water may form several basal layers in the course of time. Such a B.I.L. is of course much more recent than the glacier ice above and this situation explains the contrast in ${ }^{210} \mathrm{~Pb}$ activity. Some values encountered in the B.I.L. reach the ${ }^{210} \mathrm{~Pb}$ activity of a fresh snowfall (mean value: $4 \mathrm{dpm} / \mathrm{kg}$ ) indicating that the accretion process described is operating at the present time.

\section{Conclusions}

On the basis of location, stratigraphy, and chemistry, two origins can be suggested for the B.I.L. of Alpine glaciers:

(I) A basal accretion process occurs by refreezing of melt water squeezed out of the ice because of pressure fluctuations which change the pressure-melting point. Accretion by refreezing requires an open thermal system and is possible either because of the contribution of cold air even in the central part of the glacier (Vivian, 1975) or because of the presence of cold patches (Robin, I976) or permafrost (Haerberli, 1976) in the down-glacier direction.

(2) A basal lateral accretion process occurs at the border of the glacier due to a supply of blowing snow and melt water from this snow at the interface where a decollement takes place. B.I.L.

In certain cases, the two processes may together contribute to the constitution of a single

\section{AcKNOWLEDGEMENTS}

A grant received from the Belgian Science Foundation for this study is gratefully acknowledged. Easy access to Glacier de Tsijiore Nouve was provided by Grande Dixence S.A. Thanks for this are due to Ing. Bezinge and Ing. Arlettaz. We are also indebted to Dr Barsch, Dr Haeberli, and Dr Röthlisberger for the possibility of working at the Grubengletscher subglacial tunnel and for fruitful discussions.

\section{MS. received 3I May 1977 and in revised form 7 September 1977}

\section{REFERENCES}

Boulton, G. S. 1970. On the origin and transport of englacial debris in Svalbard glaciers. Fournal of Glaciology, Vol. 9, No. 56, p. $213^{-29}$.

Clapperton, C. M. 1975. The debris content of surging glaciers in Svalbard and Iceland. Journal of Glaciology, Vol. 14 , No. 72 , p. 395-406.

Crozaz, G. Unpublished. Mise au point d'une méthode de datation des glaciers basée sur la radioactivité du plomb-2 10. [Ph.D. thesis, Université Libre de Bruxelles, 1967.]

Crozaz, G., and others. 1964. Antarctic snow chronology with $\mathrm{Pb}^{210}$, [by] G. Crozaz, E. [E.] Picciotto, W. De Breuck. Journal of Geophysical Research, Vol. 69, No. 12, p. 2597-604. 
Gross, G. W. 1968. Some effects of trace inorganics on the ice/water system. (In Gould, R. F., ed. Trace inorganics in water. Washington, D.C., American Chemical Society, p. 27-97. (Advances in Chemistry Series, 73.))

Haeberli, W. 1976. Eistemperaturen in den Alpen. Zeitschrift für Gletscherkunde und Glazialgeologie, Bd. I1, Ht. 2, 1975, p. 203-20.

Hallet, B. $1976[\mathrm{a}]$. Deposits formed by subglacial precipitation of $\mathrm{CaCO}_{3}$. Geological Society of America. Bulletin, Vol. 87, No. 7, p. 1003-15.

Hallet, B. $1976[\mathrm{~b}]$. The effect of subglacial chemical processes on glacier sliding. Journal of Glaciology, Vol. 1 7, No. 76, p. 209-21.

Hallet, B., and others. In press. Composition of basal ice from a glacier sliding over limestones, by B. Hallet, R. D. Lorrain and R. A. Souchez. Geological Society of America. Bulletin.

Kamb, W. B., and LaChapelle, E. R. 1964. Direct observation of the mechanism of glacier sliding over bedrock. Journal of Glaciology, Vol. 5, No. 38, p. $159-72$.

Kasser, P., and Aellen, M. 1974. Les variations des glaciers suisses 1970-1971. Publication de la Commission des Glaciers de la Société Helvétique des Sciences Naturelles. $92^{\mathrm{e}}$ Rapport.

Lemmens, M., and Roger, M. In press. Influence of an ion exchange on dissolved load of alpine meltwaters. Earth Surface Processes.

Lliboutry, L. A. 1964-65. Traité de glaciologie. Paris, Masson et Cie. 2 vols.

Malo, B. A., and Baker, R. A. 1968. Cationic concentration by freezing. (In Gould, R. F., ed. Trace inorganics in water. Washington, D.C., American Chemical Society, p. 149-63. (Advances in Chemistry Series, 73.))

Prantl, F. S., and others. 1973. Alpine glacier studies with nuclear methods, [by] F. A. Prantl, W. Ambach and $\mathrm{H}$. Eisner. (In [International Hydrological Decade.] The role of snow and ice in hydrology. Proceedings of the Banff symposia, September 1972 .... Paris, UNESCO; Geneva, WMO; Budapest, IAHS, Vol. 1, p. 435-44. [IAHS-AISH Publication No. 107.])

Robin, G. de Q. 1976. Is the basal ice of a temperate glacier at the pressure melting point? Fournal of Glaciology, Vol. 16 , No. 74 , p. $183-96$.

Souchez, R. A., and Lorrain, R. D. 1975. Chemical sorting effect at the base of an Alpine glacier. Journal of Glaciology, Vol. 14 , No. 71 , p. $261-65$.

Souchez, R. A., and others. 1973. Refreezing of interstitial water in a subglacial cavity of an Alpine glacier as indicated by the chemical composition of ice, by R. A. Souchez, R. D. Lorrain and M. M. Lemmens. Fournal of Glaciology, Vol. 12, No. 66, p. 453-59.

Vivian, R. I975. Les glaciers des Alpes occidentales. Grenoble, Imprimerie Allier.

Weertman, J. 196r. Mechanism for the formation of inner moraines found near the edge of cold ice caps and ice sheets. Journal of Glaciology, Vol. 3, No. 30, p. 965-78. 